\title{
Annex 1
}

Results of the general elections in Nusa Tenggara Timur for the national parliament in Jakarta (DPR-RI)

\begin{tabular}{llrr}
\hline Ranking & Political Party & Votes & \multicolumn{1}{c}{$\%$} \\
\hline 1 & Partai Golongan Karya & 758,669 & 37.03 \\
2 & Partai Demokrasi Indonesia Perjuangan & 395,619 & 19.31 \\
3 & Partai Damai Sejahtera & 120,340 & 5.87 \\
4 & Partai Demokrat & 83,281 & 4.07 \\
5 & Partai Keadilan dan Persatuan Indonesia & 76,719 & 3.74 \\
6 & Partai Penegak Demokrasi Indonesia & 71,540 & 3.49 \\
7 & Partai Kebangkitan Bangsa & 54,031 & 2.64 \\
8 & Partai Persatuan Demokrasi Kebangsaan & 54,004 & 2.64 \\
9 & Partai Pelopor & 51,917 & 2.53 \\
10 & Partai Persatuan Pembangunan & 38,330 & 1.87 \\
11 & Partai Karya Peduli Bangsa & 34,374 & 1.68 \\
12 & Partai Nasional Banteng Kemerdekaan & 33,820 & 1.65 \\
13 & Partai Merdeka & 33,496 & 1.63 \\
14 & Partai Patriot Pancasila & 33,229 & 1.63 \\
15 & Partai Persatuan Daerah & 31,018 & 1.51 \\
16 & Partai Nasional Indonesia Marhaenisme & 29,515 & 1.44 \\
17 & Partai Amanai Nasional & 29,398 & 1.44 \\
18 & Partai Buruh Sosial Demokrat & 25,775 & 1.26 \\
19 & Partai Bulan Bintang & 24,243 & 1.18 \\
20 & Partai Sarikat Indonesia & 22,237 & 1.09 \\
21 & Partai Perhimpunan Indonesia Baru & 20,470 & 1.00 \\
22 & Partai Keadilan Sejahtera & 19,827 & 0.97 \\
23 & Partai Bintang Reformasi & 6,829 & 0.33 \\
24 & Partai Persatuan Nahlatul Ummah Indonesia & 14 & 0.00 \\
\hline Total & & $2,048,695$ & \\
\hline & & &
\end{tabular}

Source: Pemi Apriyanto, Database Pemilu 2004. Jakarta: Spirit Research and Database, p. 421. 


\section{Annex 2}

Origin of the votes for each pair of candidates in the direct district head elections (pilkada) in West Sumba, June 2005 (in \%).

\begin{tabular}{llrrrrr}
\hline Kecamatan & Home area of & Pair 1 & Pair 2 & Pair 3 & Pair 4 & Pair 5 \\
\hline Waijewa & T. Langgar & 3.2 & 0.9 & 1.3 & 0.2 & 23.3 \\
South & Y. Bobo & 9.8 & 6.3 & 37.9 & 2.3 & 11.5 \\
East & Markus DT & 28.8 & 4.1 & 10.9 & 2.0 & 12.6 \\
West & 5.6 & 1.9 & 3.5 & 0.5 & 3.0 \\
North & no & 8.5 & 33.0 & 8.5 & 7.4 & 7.2 \\
Kodi & Kornelis/Horo & 3.2 & 10.6 & 4.0 & 6.5 & 5.8 \\
Kodi Bangedo & no & 0.8 & 1.4 & 7.0 & 34.7 & 1.9 \\
Katikutana & Bintang & & & & & \\
Umbu Ratu & & 1.7 & 1.3 & 1.9 & 8.7 & 2.6 \\
Nggai & Dedu Ngara & 1.3 & 3.0 & 4.4 & 4.8 & 1.5 \\
Memboro & no & & & & & \\
& Pote Leba/ & 2.4 & 11.5 & 2.4 & 4.7 & 5.3 \\
Loli & Dapawole & 2.8 & 9.6 & 2.3 & 8.3 & 7.7 \\
Waikabubak & & 8.2 & 8.9 & 6.0 & 4.8 & 5.1 \\
Loura & & 2.8 & 2.8 & 6.6 & 8.3 & 7.2 \\
Lamboya & & 0.5 & 3.6 & 2.1 & 6.1 & 4.2 \\
Wanukaka & & 20.3 & 1.1 & 1.2 & 0.5 & 1.2 \\
Tana Righu & Yubi Pandango & 100.0 & 100.0 & 100.0 & 100.0 & 100.0 \\
\hline Total & & & & &
\end{tabular}

Source: Data from General Election Committee (KPU) in West Sumba. 